\title{
Oligosaccharides from human milk influence growth-related characteristics of intestinally transformed and non-transformed intestinal cells
}

\author{
Sabine Kuntz ${ }^{1}$, Silvia Rudloff ${ }^{1,2}$ and Clemens Kunz ${ }^{1 *}$ \\ ${ }^{1}$ Institute of Nutritional Science, Justus-Liebig-University Giessen, Wilhelmstrasse 20, D-35392 Giessen, Germany \\ ${ }^{2}$ Department of Pediatrics, Justus-Liebig-University Giessen, Feulgenstrasse 12, 35392 Giessen, Germany
}

(Received 28 March 2007 - Revised 9 July 2007 - Accepted 12 July 2007)

Human milk oligosaccharides (HMO) are considered to influence the composition of the gut microflora in breastfed infants. We investigated direct effects of milk HMO fractions or individual oligosaccharides on proliferation, differentiation and apoptosis in transformed human intestinal cells (HT-29 and Caco-2) and non-transformed small intestinal epithelial crypt cells of fetal origin (human intestinal epithelial cells; HIEC). We observed growth inhibition induced by neutral and acidic HMO fractions in HT-29, Caco-2 and HIEC cells in a dose dependent manner. However, the effects varied between cell lines, i.e. HT-29 and Caco-2 cells were more sensitive than HIEC cells. In HT-29, all 16 individual neutral and acidic oligosaccharides except from the two fucosyllactoses had an inhibitory effect on cell growth. Regarding the induction of differentiation in HT-29 and HIEC cells a threshold concentration was observed at $7.5 \mathrm{mg} / \mathrm{ml}$ for neutral and acidic HMO fractions. Among individual oligosaccharides, only sialyllactoses induced differentiation in HT-29 and HIEC cells; no effect neither of fractions nor of individual oligosaccharides was found in Caco-2 cells. A strong induction of apoptosis was only detected in HT-29 and HIEC cells for neutral oligosaccharide but not for acidic fractions. HMO were shown to induce growth inhibition in intestinal cells through two different mechanisms, by suppressing cell cycle progression through induction of differentiation and/or by influencing apoptosis. As the development and maturation of digestive and absorptive processes depend on differentiation our experiments show that oligosaccharides are effective at influencing various stages in gastrointestinal development in vitro.

Oligosaccharides: Intestinal cells: Proliferation: Differentiation: Apoptosis

Human milk seems to have numerous benefits for infants including a reduced risk for neonatal inflammatory diseases (necrotising enterocolitis and allergic colitis) or respiratory infections ${ }^{1-3}$. Although the components that cause these effects are not known yet human milk oligosaccharides (HMO) belong to potential candidates.

Oligosaccharides from human milk have been discussed to be growth promoting factors for the bifidobacteria dominated flora in the gut of breastfed infants ${ }^{4}$. In addition, these carbohydrates may have a more specific effect on the colonisation of the gut by acting as soluble analogues to epithelial receptors for specific microbes and may thus prevent their adhesion to the intestinal wall ${ }^{5}$. As the human gut hosts a diverse collection of microorganisms the host microbe interactions are currently an important research topic ${ }^{6}$. To better understand the interactions of HMO with various micro-organisms it is certainly necessary to characterise the specific components and to investigate the underlying mechanisms. Also, it has recently been shown that HMO inhibit leucocyte adhesion to activated endothelial cells and may influence neutrophil platelet interactions $^{7,8}$.

Regarding the biosynthesis of HMO the human mammary gland is thought to be the only organ where lactose and lactose-derived oligosaccharides are synthesised. A $\beta 1.4-$ galactosyltransferase as housekeeping enzyme links galactose to glucose instead of $\mathrm{N}$-acetyl glucosamine to form lactose which is then used for the assembly of $\mathrm{HMO}^{9,10}$.

The amount of HMO depends on the lactational stage of the women; it is highest in colostrum (days 1-4 post-partum), but even mature milk ( $>$ day 10 postpartum) contains oligosaccharides in concentrations up to $15 \mathrm{~g} / 1$ or more ${ }^{11,12}$. There is also an individual variation of HMO due to the specificity of the mother's blood group and secretor status ${ }^{13}$. In the past more than 150 HMO have been characterised which can be separated into a neutral and an acidic HMO fraction depending on the presence of one or more sialic acid $(N$-acetylneuraminic acid) residues.

Assuming an average milk intake of 1 litre/d, breastfed infants receive about $15 \mathrm{~g}$ HMO per day or more. As these components are considered to be indigestible in the infant's gastrointestinal tract, the intestine of the breastfed infant is continuously exposed to very high concentrations of $\mathrm{HMO}^{14-17}$. Due to their unique structures, milk oligosaccharides do have the potential to modulate intestinal development and functions ${ }^{13,18-21}$. The gastrointestinal tract of the newborn undergoes maturational changes in the early post-

Abbreviations: HIEC, human intestinal epithelial cells; HMO, human milk oligosaccharides.

* Corresponding author: Dr Clemens Kunz, fax +49 6419939049, email Clemens.Kunz@ernaehrung.uni-giessen.de 
natal period to develop its full function for digestion and absorption or as a barrier and as an immunological active organ. Renewal of the intestinal villi occurs through a highly regulated process of proliferation, differentiation and apoptosis $^{22-24}$. Human milk has been found to stimulate gastrointestinal mucosal proliferation and maturation in animal models and is thought to protect the infant from harmful environmental factors by affecting the mucosal bar$\operatorname{rier}^{20,21,25,26}$. So far, no reports focusing on the growth-related effects of HMO fractions or individual oligosaccharides within the human gastrointestinal tract have been published.

For studying the effect of oligosaccharides on intestinal growth-related events we used three epithelial cell lines: human intestinal epithelial cells (HIEC), HT-29 and Caco-2 which vary in their degree of differentiation (Fig. 1). The HIEC cell line was generated from normal human fetal intestine. The morphological und functional characterisation of HIEC cells provided evidence that they are comparable with undifferentiated cells of the crypts ${ }^{26}$. They express a number of crypt cell but no villus cell markers and appear to be unable to differentiate when reaching confluence ${ }^{27,28}$. Thus, they are considered to be intestinal stem-like cells ${ }^{29}$. HT-29 cells also represent a very low differentiated phenotype such as normal crypt colonocytes. Similar to HIEC cells they are unable to differentiate after reaching confluence. Caco-2 cells are derived from a well characterised cell line used as a model of intestinal epithelial cells. Under pre-confluent conditions, the cells reveal a moderate differentiation status; however, upon reaching confluence they spontaneously undergo a gradual villus-like enterocytic differentiation process similar to that observed in the epithelium of the intact fetal small and large bowel. Under culture conditions, cells grow as a monolayer and show typical cylindrical polarised morphology with apical microvilli and brush-border associated enzymes dependent on the degree of differentiation ${ }^{30,31}$. Thus, under the conditions used in our experiments pre-confluent Caco-2 as well as HT-29 and HIEC cells comprise the proliferation compartment of the crypt/villus axis simulating the situation in the fetal and neonatal intestine. As is well known that nutritional factors are able to induce differentiation under such pre-

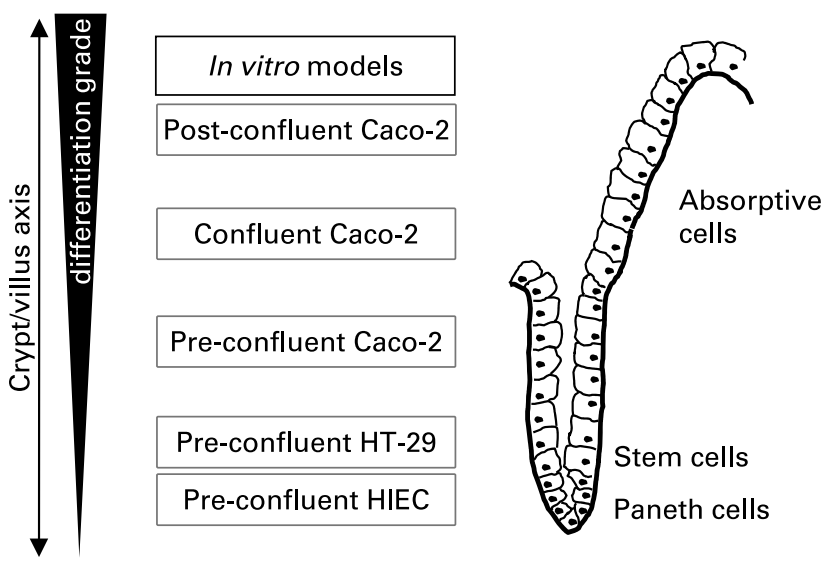

Fig. 1. Experimental in vitro model of proliferating cells which vary in their stage of differentiation. Alkaline Phosphatase activity in unstimulated preconfluent control cells was used as a marker of differentiation. AP activity was $0.193 \pm 0.023 / \mathrm{h} / 10^{6}$ cells in HT-29, $0.185 \pm 0.005 / \mathrm{h} / 10^{6}$ cells in HIEC and $0.609 \pm 0.013 / \mathrm{h} / 10^{6}$ cells in Caco-2. confluent conditions by for example, modifying cell culture medium or nutrient supply ${ }^{32,33}$. our objective was to investigate whether cell dynamics in these cell lines are affected by milk oligosaccharides.

\section{Experimental methods}

Isolation of human oligosaccharides from human milk and human milk oligosaccharide preparation

Oligosaccharides were isolated from human milk as described previously ${ }^{34,35}$. Briefly, after centrifugation, the lipid layer was removed, and proteins were precipitated from the aqueous phase using ice-cold ethanol. Lactose was removed by gel filtration on Sephadex G-25 (Pharmacia Biotech, Uppsala, Sweden). The total oligosaccharide fraction was further separated into an acidic fraction (aHMO) and a neutral fraction (nHMO) using HPLC anion-exchange chromatography on a Resource Q column (Pharmacia Biotech).

\section{Oligosaccharide analysis}

Oligosaccharide analysis was performed by high $\mathrm{pH}$ anionexchange chromatography with pulsed amperometric detection (HPAEC-PAD) on a CarboPac PA1 column (Dionex, Sunnyvale, CA, USA) using the conditions described previously ${ }^{8}$.

\section{Oligosaccharide standards}

Oligosaccharide standards shown in Tables 1 and 2 were obtained from Dextra Laboratories (Reading, Berks, UK).

\section{Oligosaccharide concentrations used for cell culture studies}

Neutral and acidic HMO fractions for cell culture studies were used at $5,7.5$ and $15 \mathrm{mg} / \mathrm{ml}$ for differentiation and apoptosis, whereas the dose dependent effect on proliferation has been investigated with concentrations between 0 to $15 \mathrm{mg} / \mathrm{ml}$; individual oligosaccharides have been tested at $1 \mathrm{mg} / \mathrm{ml}$.

\section{Cell culture}

To investigate effector-mediated growth and differentiation events, HIEC, HT-29 and Caco-2 cells were used in the exponential growth phase under pre-confluence conditions ${ }^{31,36}$.

HT-29 cells. The human colon carcinoma cell line HT-29 was obtained from the American Type Culture Collection (ATCC, Rockville, MD, USA) and was used between passages 40 and $50^{37}$.

Caco-2 cells. Caco-2 cells were a gift from Professor R. K. H. Kinne at the Max-Planck-Institute of Molecular Physiology (Dortmund, Germany). They were used between passages 35 and 50.

HIEC cells. The human small intestinal epithelial crypt cells of fetal origin (HIEC) were generously donated by J.F. Beaulieu (Department of Anatomy and Cell Biology, Faculty of Medicine, Université de Sherbrooke, Sherbrooke, Quebec, Canada). HIEC cells were used between passages 15 and $20^{38}$.

All cell lines were cultured in $75 \mathrm{~cm}^{2}$ tissue culture flasks (Renner, Dannstadt, Germany) in RPMI 1640 (Roswell Park 
Table 1. Structures of selected neutral oligosaccharides for cell culture studies

\begin{tabular}{|c|c|c|}
\hline Abbreviation & Compound & Structure \\
\hline LNT & Lacto-N-tetraose & Gal $\beta 1-3 G|c N A c \beta 1-3 G a| \beta 1-4 G \mid c$ \\
\hline $\mathrm{LNH}$ & Lacto-N-hexaose & $\begin{array}{r}\text { Gal } \beta 1-4 \mathrm{GlcNAc} \beta 1-6 \text { Gal } \beta 1-4 \mathrm{Glc} \\
3 \\
\text { Gal } \beta 1-4 \mathrm{GlcNAc} \beta 1\end{array}$ \\
\hline LNFP I & Lacto-N-fucopentaose I & $\begin{array}{l}\text { Gal } \beta 1-3 \mathrm{GlCNAC} \beta 1-3 \mathrm{Gal} \beta 1-4 \mathrm{Glc} \\
2 \\
\quad \mid \\
\text { Fuc } \alpha 1\end{array}$ \\
\hline LNFP ॥ & Lacto-N-fucopentaose II & $\begin{array}{c}\text { Gal } \beta 1-3 \mathrm{Glc} N A c \beta 1-3 \mathrm{Gal} \beta 1-4 \mathrm{Glc} \\
4 \\
\mid \\
\text { Fuc } \alpha 1\end{array}$ \\
\hline LNFP III & Lacto-N-fucopentaose III & $\begin{array}{c}\text { Gal } \beta 1-4 \mathrm{GlcNAc} \beta 1-3 \mathrm{Gal} \beta 1-4 \mathrm{Glc} \\
3 \\
\mid \\
\text { Fuc } \alpha 1\end{array}$ \\
\hline LNDFH I & Lacto-N-difucohexaose I & $\begin{array}{cc}\text { Gal } \beta 1-3 G \mid c N A c \beta 1-3 G a l \beta 1-4 G l c \\
2 & 4 \\
\mid & \mid \\
\text { Fuc } \alpha 1 & \text { Fuc } \alpha 1\end{array}$ \\
\hline LNDFH II & Lacto-N-difucohexaose II & $\begin{array}{rc}\text { Gal } \beta 1-3 G l c N A c \beta 1-3 G a l & \beta 1-4 G l c \\
4 & 3 \\
\mid & \mid \\
\text { Fuc } \alpha 1 & \text { Fuc } \alpha 1\end{array}$ \\
\hline $\begin{array}{l}2^{\prime} \mathrm{FL} \\
3-\mathrm{FL}\end{array}$ & $\begin{array}{l}\text { 2'-Fucosyllactose } \\
\text { 3-Fucosyllactose }\end{array}$ & $\begin{array}{l}\text { Fuc } \alpha 1-2 \text { Gal } \beta 1-4 \mathrm{Glc} \\
\text { Gal } \beta 1-4 \mathrm{Glc} \\
3 \\
\mid \\
\text { Fuc } \alpha 1\end{array}$ \\
\hline
\end{tabular}

Memorial Institute media) for HT-29 and HIEC cells or Dulbecco's Modified Eagle Medium (Caco-2) supplemented with $10 \%$ fetal calf serum and $2 \mathrm{~mm}$ glutamine (Invitrogen, Karlsruhe, Germany). The cultures were maintained in a humidified atmosphere of $5 \% \mathrm{CO}_{2}$ at $37^{\circ} \mathrm{C}$. Cells were passaged at preconfluent densities by using $0.05 \%$ trypsin and $0.5 \mathrm{~mm}-$ EDTA (Invitrogen, Karlsruhe, Germany).
Measurement of cell proliferation with -(4,5-dimethylthiazol2-yl)-2,5-diphenyltetrazoliumbromide assay

Proliferation of cells was determined with the 3-(4,5-dimethylthiazol-2-yl)-2,5-diphenyltetrazoliumbromide assay. Regarding the different duplication times of the cell lines the initial seeding density of Caco-2 and HT-29 were 1500 and 2500 cells

Table 2. Structures of selected acidic oligosaccharides for cell culture studies

\begin{tabular}{|c|c|c|}
\hline Abbreviation & Compound & Structure \\
\hline SL & $\mathrm{N}$-Acetyl-neuraminyl lactose & $\begin{array}{l}\text { Mixture of } 3^{\prime} \mathrm{SL} \text { and } 6{ }^{\prime} \mathrm{SL}(80 \%) \text { Remainder } \\
\text { primarily 6'-Sialyllactosamin (less than } 5 \% \text { lactose) }\end{array}$ \\
\hline $3^{\prime}-\mathrm{SL}$ & 3'-Sialyllactose & Neu5Ac $\alpha 2-3 G a l \beta 1-4 G l c$ \\
\hline $6^{\prime}-\mathrm{SL}$ & 6'-Sialyllactose & Neu5Ac $\alpha 2-6 \mathrm{Gal} \beta 1-4 \mathrm{Glc}$ \\
\hline LST a & LS-Tetrasaccharide a & $\begin{array}{c}\text { Gal } \beta 1-3 \mathrm{GlcNAc} \beta 1-3 \mathrm{Gal} \beta 1-4 \mathrm{Glc} \\
3 \\
\mid \\
\text { Neu5Ac } \alpha 2\end{array}$ \\
\hline LST b & LS-Tetrasaccharide b & $\begin{array}{c}\text { Gal } \beta 1-3 G \mid c N A c \beta 1-3 G a l \beta 1-4 G l c \\
6 \\
\mid \\
\text { Neu5Ac } \alpha 2\end{array}$ \\
\hline LST c & LS-Tetrasaccharide $\mathrm{c}$ & $\begin{array}{c}\text { Gal } \beta 1-4 \mathrm{GlcNAc} \beta 1-3 \mathrm{Gal} \beta 1-4 \mathrm{Glc} \\
6 \\
\mid \\
\text { Neu5Ac } \alpha 2\end{array}$ \\
\hline DSLNT & Disialyl-lacto-N-tetraose & $\begin{array}{cl}\text { Gal } \beta 1-3 G \mid c N A c \beta 1-3 G a l \beta 1-4 G l c \\
3 & 6 \\
\mid & \mid \\
\text { Neu5Ac } \alpha 2 & \text { Neu5Ac } \alpha 2\end{array}$ \\
\hline
\end{tabular}


per well for HIEC on ???96-well plates. After initial seeding they were grown in media with supplements and allowed to adhere for $24 \mathrm{~h}$. Thereafter, medium was replaced and cells were exposed to variable concentrations of oligosaccharides dissolved in cell culture medium ( $\mathrm{pH} 7.4)$ and cells were allowed to grow for another $72 \mathrm{~h}$. Relative cell numbers were determined by incubating the cells with 3-(4,5-dimethylthiazol-2-yl)-2,5-diphenyltetrazoliumbromide (Calbiochem, Bad Soden, Germany) for $3 \mathrm{~h}$. The resulting intracellular purple formazan was solubilised in a solution of $10 \% \mathrm{Na}$ dodecyl sulfate and $0 \cdot 1 \mathrm{M} \mathrm{HCl}$ and quantified by spectrophotometry (absorbance was measured at wavelength of $550 \mathrm{~nm}$ ) after $5 \mathrm{~h}$ using an ELISA microplate reader (Asys, Eugendorf, Austria). Cell numbers were determined based on a calibration curve using cell counts between 500 and 30000 .

\section{apoptosis}

Caspase-3-like activity was assessed as described ${ }^{39-41}$ and served as an early apoptosis marker. Briefly, all cell lines were seeded at a density of 50000 cells per well on 6-well plates and allowed to adhere for $24 \mathrm{~h}$. Cells were then incubated for $24 \mathrm{~h}$ in the absence (control) or presence of oligosaccharides. Subsequently, cells were trypsinised, cell numbers were determined and then the cells were centrifuged at $400 \mathrm{~g}$ for $3 \mathrm{~min}$. Cytosolic extracts were prepared according to Nicholson et $a l^{41}$ and finally the cytosolic supernatant fraction was incubated with the colorimetric caspase- 3 tetrapeptide-substrate $\mathrm{N}$-acetyl-Asp-Glu-Val-Asp-p-nitroanilide (Calbiochem, Bad Soden, Germany) at a final concentration of $20 \mu \mathrm{M}$. Cleavage of the caspase-3 substrate was determined by using the microplate reader (Asys, Eugendorf Austria) at a wavelength of $405 \mathrm{~nm}$; the apopain activity was measured as $\Delta \mathrm{E} / \mathrm{h} / 10^{6}$ cells and the control was set to $100 \%$.

\section{Statistical analysis}

We applied a nonlinear approximation model, using the least square method, to derive the ??? $\mathrm{IC}_{50}$ values for growth inhibition; ??? $\mathrm{IC}_{50}$ was defined as the concentration by which the cell growth is reduced by half times in comparison to the end point. This model was based on a competition curve using 1 component. Data were evaluated by one-way ANOVA and statistical differences were tested by Bonferroni's post hoc test. For each variable at least three independent experiments (three replications) were carried out and the results were expressed as mean values with their standard errors (SEM). All analyses were carried out with the GraphPad Software Prism 3 (San Diego, CA, USA); differences were considered significant at $* P<0.05$ and $* * P<0.01$.

\section{Results}

Fractions of neutral and acidic oligosaccharides were isolated from human milk and further separated by HPAEC-PAD as shown in Fig. 2. Based on the quantitative abundance of specific compounds after HPAEC-PAD oligosaccharide standards were selected (Tables 1 and 2) to determine their effects on intestinal cell proliferation, differentiation and apoptosis.

\section{Influence of oligosaccharide fractions and isolated compounds on proliferation}

Neutral and acidic oligosaccharide fractions exerted a pronounced effect on intestinal cell proliferation in all cell lines in a dose-dependent manner after $72 \mathrm{~h}$ of exposure (Figs. 3 (A) and (B)). Compared with control experiments, neutral oligosaccharides reduced proliferation rates with $\mathrm{IC}_{50}$ values of 2.33 (SEM 0.01) mg/ml, 0.34 (SEM 0.01) mg/ml and 0.20 (SEM 0.00$) \mathrm{mg} / \mathrm{ml}$ in HT-29, Caco-2 and HIEC cells, respectively. When the cells were exposed to the highest neutral HMO concentration $(15 \mathrm{mg} / \mathrm{ml})$, the potency of growth inhibition was reduced to 41.73 (SEM 8.18) \% in HT-29, to 62.49 (SEM 3.54) \% in Caco-2 and to 77.32 (SEM 4.03) \% in HIEC cells. In the case of acidic HMO fractions a similar dose-dependent effect was observed. The $\mathrm{IC}_{50}$ values for acidic HMO varied between the intestinal cell lines, i.e. cell growth was inhibited at a $\mathrm{IC}_{50}$ values of 0.29 (SEM 0.01) $\mathrm{mg} / \mathrm{ml}, 0.71$ (SEM 0.01) $\mathrm{mg} / \mathrm{ml}$ and 1.62 (SEM 0.02) $\mathrm{mg} / \mathrm{ml}$ for HT-29, Caco-2 and HIEC cells, respectively. At the highest concentration of acidic HMO $(15 \mathrm{mg} / \mathrm{ml})$, cell growth was reduced to 31.56 (SEM 4.62) \% for HT-29, to 53.80 (SEM 8.38) $\%$ for Caco-2 and to 65.68 (SEM 3.98) \% for HIEC cells with differences in potency. These growth inhibition effects were not due to cytotoxic side-effects, because nonviable cells, as determined by trypan blue staining, were counted on a haemocytometer after $4 \mathrm{~h}$ of incubation and the percentage of nonviable cells in all groups was below $<5 \%$ of controls.

In order to identify responsible components for the observed growth inhibition, we selected neutral and acidic oligosaccharides occurring in human milk (Fig. 2;Tables 1 and 2) and used those as standards although in a much lower concentration in the same proliferation assay as has been described for oligosaccharide fractions. The growth inhibition at $1 \mathrm{mg} / \mathrm{ml}$ is shown in Table 3. Growth of HT-29 cells was inhibited by all neutral and acidic oligosaccharides except for the two fucosyllactoses. LNDFH II, revealing the most pronounced effect in all cell lines, reduced the cell growth to 28.82 (SEM 8.55) \% for HT29 and to 63.72 (SEM 5.09) \% for Caco-2 cells; the effects in HIEC cells were less pronounced. Also, LNDFH I was able to reduce HT-29 and Caco- 2 cell growth, but no significant effects have been observed in HIEC cells. In case of LNFP I and II only HT-29 and Caco-2 cell growth was influenced; again, HIEC cells 


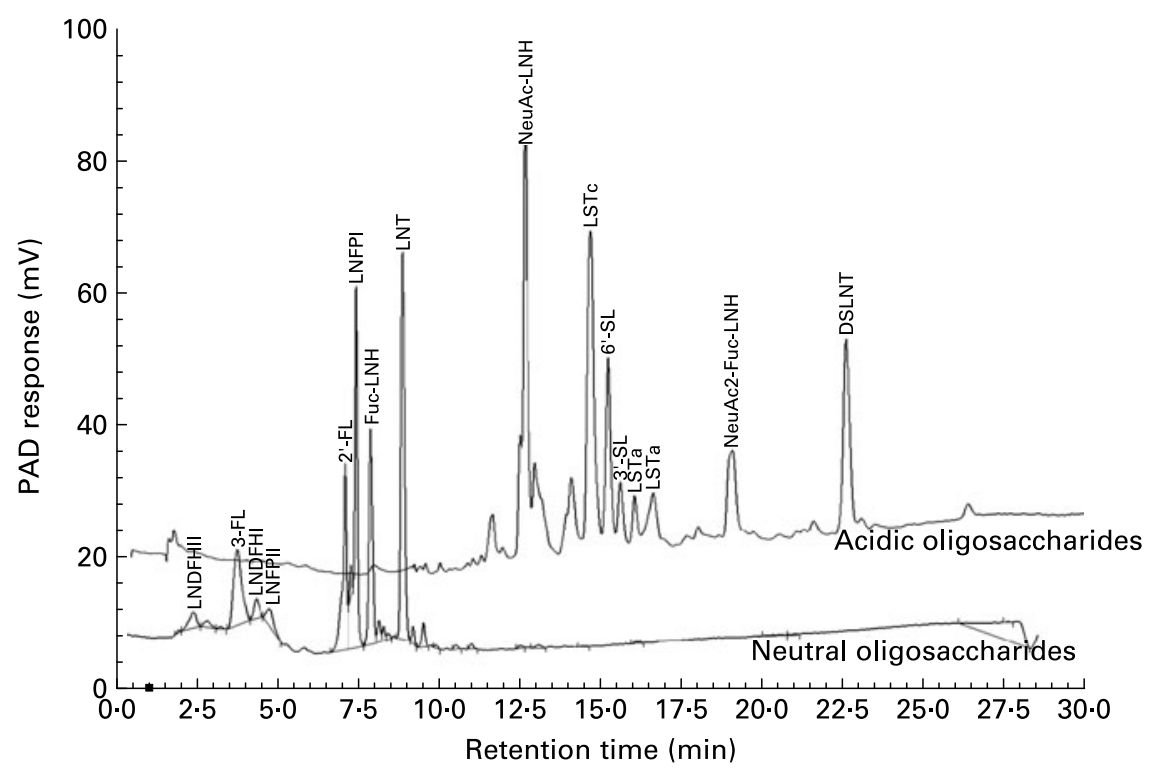

Fig. 2. HPAEC-PAD of oligosaccharide fractions separated by HPLC anion exchange. Oligosaccharides were prepared according to the procedure described in material and methods. The chromatogram represents the separation of the neutral and the acidic HMO fraction. Individual components have been identified by standard components (for abbreviations see TABLE 1 and 2).

remained unaffected. For LNT and LNH, an inhibition of cell growth was observed only in HT-29 cells.

With regard to growth inhibition, single acidic compounds also seem to be very efficacious and similar to the observed effect of most of the neutral oligosaccharide standards. All acidic compounds tested reduced the proliferation of HT-29

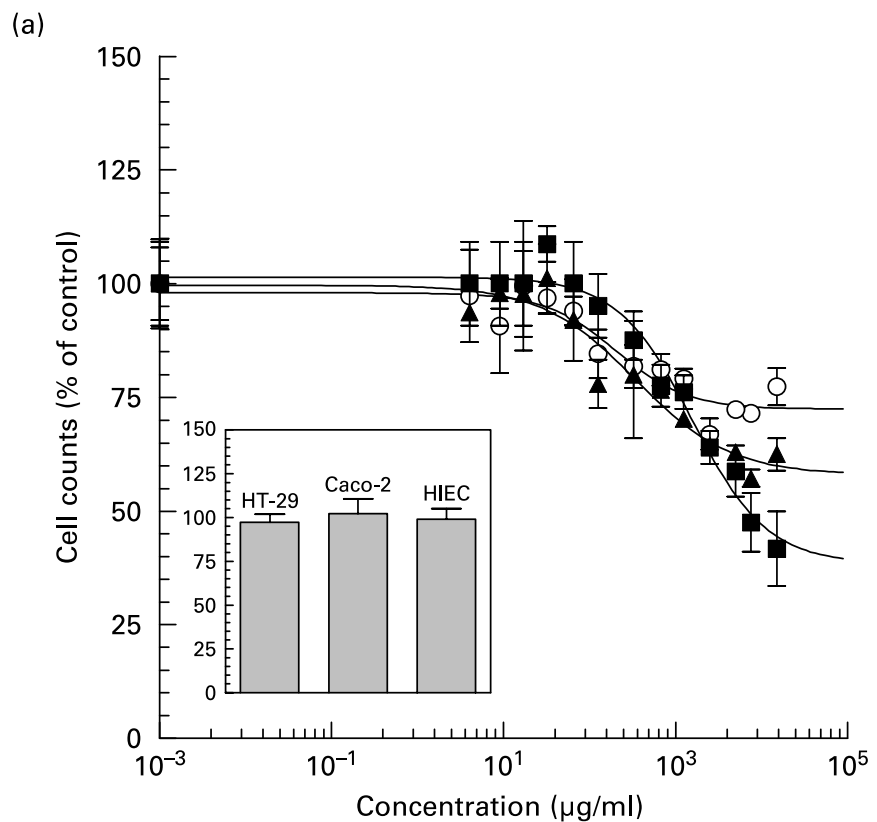

cells with $3^{\prime}$-SL, LST'a and DSLNT showing the highest impact. Also, HIEC cell proliferation was influenced by acidic compounds with the largest effects observed for LST a, LST $\mathrm{b}$ and DSLNT $(* * P<0 \cdot 01)$ followed by $3^{\prime}-\mathrm{SL}, 6^{\prime}-\mathrm{SL}$ and LST $\mathrm{c}(* P<0 \cdot 05)$. In contrast, the growth of Caco-2 cells was only influenced by DSLNT and 6'SL. (b)

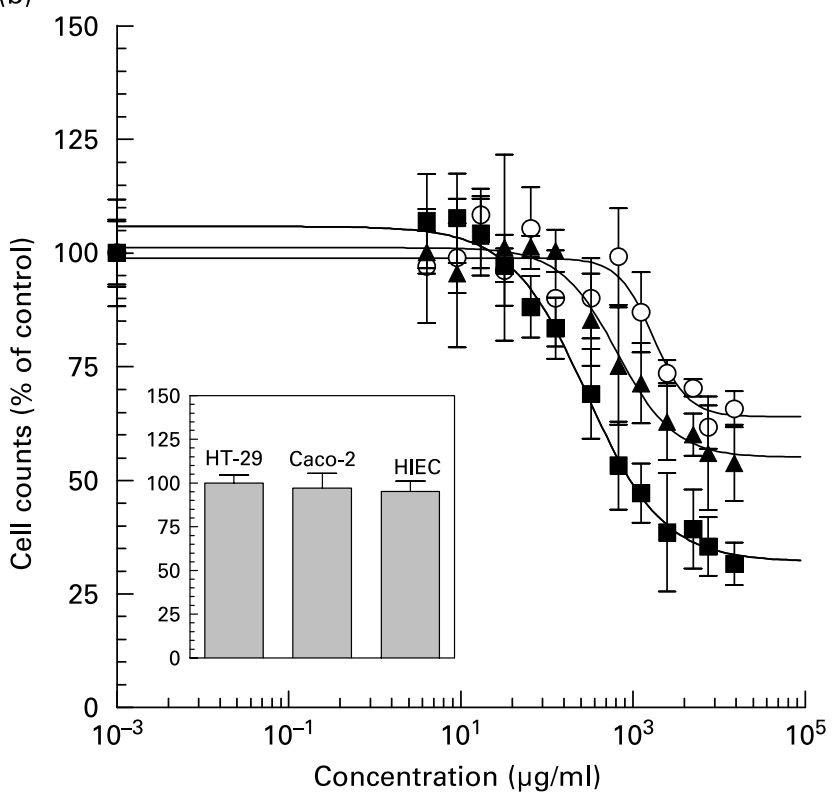

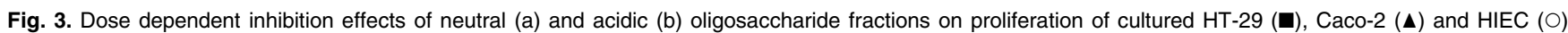
cells. HT-29, Caco-2 (1,500 per well) and HIEC (2,500 per well) cells were incubated $24 \mathrm{~h}$ to allow the cells time to attach. The cells were then left untreated (control) or treated with concentrations between $0-15 \mathrm{mg} / \mathrm{ml}$ of neutral and acidic HMO fractions for $72 \mathrm{~h}$. After $72 \mathrm{~h}$ incubation the proliferation was determined with the 3-(4,5-dimethylthiazol-2-yl)-2,5-diphenyltetrazoliumbromide (MTT) assay. The concentration that induced a $50 \%$ inhibition of cell proliferation compared with controls was calculated with a non-linear approximation model, using the least square method to derive the IC $\mathrm{C}_{50}$ values for growth inhibition. $\mathrm{FIG}$. 3 (inset). Cytotoxicity was measured after $4 \mathrm{~h}$ of incubation with $15 \mathrm{mg} / \mathrm{ml}$ oligosaccharides using the trypan blue exclusion test. Results were expressed as \% of control (untreated) and each value represents the mean \pm SEM from three independent experiments. 
Table 3. Effects of selected neutral and acidic oligosaccharides on proliferation of HT-29, Caco-2 and HIEC cells $\mathrm{s}^{1,2,3}$ (Mean values with their standard errors)

\begin{tabular}{|c|c|c|c|c|c|c|c|}
\hline \multirow[b]{2}{*}{ Abbreviation } & \multirow[b]{2}{*}{ Concentration (mm) } & \multicolumn{2}{|c|}{ HT-29 } & \multicolumn{2}{|c|}{ Caco-2 } & \multicolumn{2}{|c|}{ HIEC } \\
\hline & & Mean & SEM & Mean & SEM & Mean & SEM \\
\hline untreated & 0 & $100 \%$ & $100 \%$ & $100 \%$ & $100 \%$ & $100 \%$ & $100 \%$ \\
\hline LNT & 1.4 & $58 \cdot 0^{\star *}$ & 5.4 & $96 \cdot 5$ & 6.7 & $100 \cdot 3$ & 4.4 \\
\hline LNH & 0.9 & $68 \cdot 7^{*}$ & 4.9 & $97 \cdot 3$ & 5.9 & $102 \cdot 2$ & $4 \cdot 5$ \\
\hline LNFP I & $1 \cdot 1$ & $83 \cdot 2^{\star}$ & $5 \cdot 7$ & $74 \cdot 0^{*}$ & 5.8 & $96 \cdot 3$ & $6 \cdot 4$ \\
\hline LNFP II & $1 \cdot 1$ & $57 \cdot 3^{\star \star}$ & $5 \cdot 4$ & $65 \cdot 5^{\star \star}$ & 4.4 & $99 \cdot 2$ & $7 \cdot 2$ \\
\hline LNFP III & $1 \cdot 1$ & $59 \cdot 7^{*}$ & $7 \cdot 3$ & $78 \cdot 5^{\star}$ & $6 \cdot 6$ & $92 \cdot 2$ & $5 \cdot 3$ \\
\hline LNDFH I & 1.0 & $43 \cdot 5^{\star \star}$ & 7.9 & $83 \cdot 6^{*}$ & $5 \cdot 5$ & $88 \cdot 3$ & 5.5 \\
\hline LNDFH II & $1 \cdot 0$ & $28 \cdot 8^{\star \star}$ & 8.5 & $63 \cdot 7^{\star *}$ & $5 \cdot 0$ & $82 \cdot 2^{*}$ & 4.9 \\
\hline $2^{\prime} \mathrm{FL}$ & $2 \cdot 0$ & $80 \cdot 0$ & $7 \cdot 7$ & $102 \cdot 2$ & $5 \cdot 2$ & 99.2 & $8 \cdot 3$ \\
\hline 3-FL & $2 \cdot 0$ & $82 \cdot 8$ & $6 \cdot 3$ & $108 \cdot 1$ & $12 \cdot 2$ & 95.4 & $9 \cdot 8$ \\
\hline SL-mixture & Unknown & $50 \cdot 2^{*}$ & 8.5 & 88.4 & $6 \cdot 9$ & $60 \cdot 4^{*}$ & $5 \cdot 9$ \\
\hline $3^{\prime}-S L$ & 1.5 & $47 \cdot 7^{\star \star}$ & 5.5 & $96 \cdot 5$ & 4.4 & $66 \cdot 5^{\star}$ & 5.9 \\
\hline $6^{\prime}-S L$ & 1.5 & $62 \cdot 3^{*}$ & 8.0 & $73 \cdot 6^{\star}$ & 4.8 & $68 \cdot 5^{*}$ & $6 \cdot 0$ \\
\hline LST a & 1.0 & $60 \cdot 0^{\star \star}$ & $4 \cdot 0$ & $79 \cdot 1$ & $7 \cdot 3$ & $61 \cdot 2^{\star \star}$ & 4.9 \\
\hline LST b & 1.0 & $68 \cdot 6^{\star}$ & $10 \cdot 2$ & 99.4 & 5.8 & $60 \cdot 2^{\star \star}$ & 4.4 \\
\hline LST c & 1.0 & $62 \cdot 0^{*}$ & 4.8 & 95.5 & 8.3 & $65 \cdot 5^{\star}$ & $5 \cdot 5$ \\
\hline DSLNT & 0.8 & $54 \cdot 5^{\star \star}$ & 4.6 & $47.6^{* *}$ & $7 \cdot 4$ & $57.5^{* *}$ & $5 \cdot 5$ \\
\hline
\end{tabular}

${ }^{1}$ Each value represents the mean \pm SEM from three independent experiments ( $n 3$ ),

Influence of oligosaccharide fractions and isolated compounds on alkaline phosphatase activity as a marker of differentiation

Incubation of intestinal cells with neutral HMO fractions increased AP activity statistically significant only at the highest concentration tested $(15 \mathrm{mg} / \mathrm{ml})$ in HT-29 and HIEC cells although a tendency towards increased ???AP activity can already be observed at $7.5 \mathrm{mg} / \mathrm{ml}$ (Fig. 4 (A)). The induction of AP by neutral HMO at $15 \mathrm{mg} / \mathrm{ml}$ was 121.26 (SEM 5.48) $\%$ for HT-29 and 119.32 (SEM 5.50) \% for HIEC cells compared with controls (non-supplemented cells). In contrast, acidic oligosaccharides were able to stimulate differentiation statistically significant already at $7.5 \mathrm{mg} / \mathrm{ml}$ and reached a maximum of 145.53 (SEM 3.71) \% in HT-29 cells and 171.00 (SEM 7.78) \% in HIEC cells at $15 \mathrm{mg} / \mathrm{ml}$ (Fig. 4 (B)). In Caco-2 cells, neither neutral nor acidic oligosaccharides fractions were able to induce differentiation.

Under the same experimental conditions, individual neutral oligosaccharides were tested at a concentration of $1 \mathrm{mg} / \mathrm{ml}$ (Table 4). Only LNDFH II was able to induce AP activity in HT-29 cells, whereas all other standards were ineffective in the three cell lines. Among acidic oligosaccharides, sialyllactoses $\left(3^{\prime}-\mathrm{SL}, 6^{\prime}-\mathrm{SL}\right.$ or a mixture of both) exerted a moderate but significant AP stimulating effect in HT-29 cells and on HIEC cells, but not on Caco-2 cells.
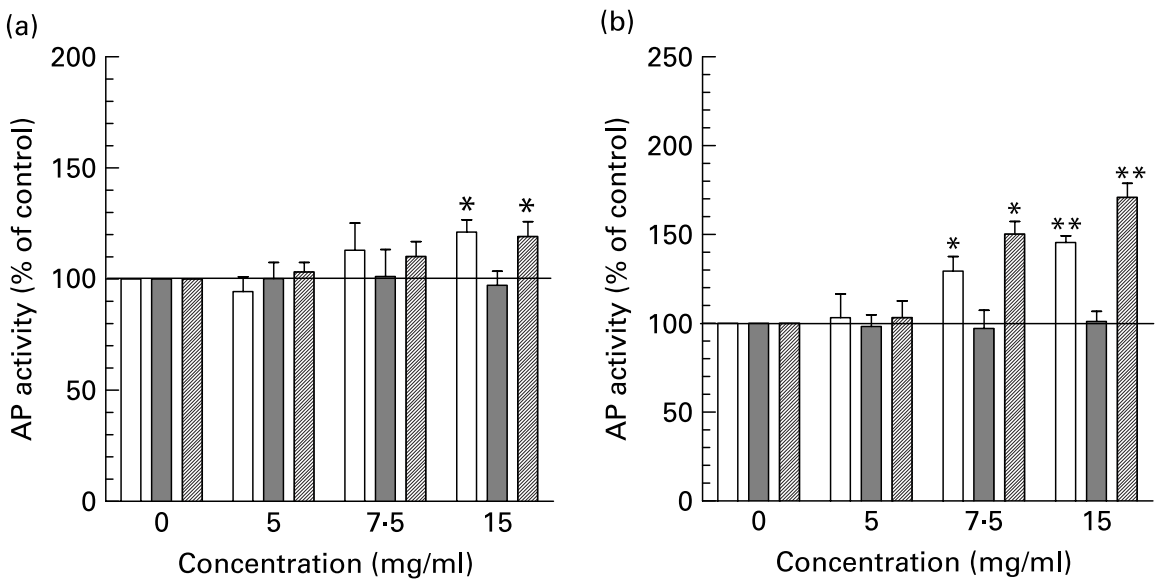

Fig. 4. Determination of differentiation in intestinal cells after incubation with neutral (a) and acidic (b) HMO fractions. Alkaline phosphatase (AP) activity of intestinal HT-29, Caco-2 and HIEC cells exposed to $0,5,7.5$ and $15 \mathrm{mg} / \mathrm{ml}$ neutral or acidic HMO was determined after $72 \mathrm{~h}$ of incubation as indicated in materials and methods. AP activity in control cells was $0.193 \pm 0.023 / \mathrm{h} / 10^{6}$ cells $(\mathrm{HT}-29), 0.185 \pm 0.005 / \mathrm{h} / 10^{6}$ cells $(\mathrm{HIEC})$ and $0.609 \pm 0.013 / \mathrm{h} / 10^{6}$ cells $($ Caco-2) and was set to $100 \%$. Values (\% of control) are given as mean \pm SEM (n $3 ;{ }^{*} P<0.05$ and ${ }^{* \star} P<0.01$ ). 
Table 4. Effects of selected neutral and acidic oligosaccharides $(1 \mathrm{mg} / \mathrm{ml})$ on differentiation of HT-29, Caco-2 and HIEC cells ${ }^{1,2,3}$

(Mean values with their standard errors)

\begin{tabular}{|c|c|c|c|c|c|c|}
\hline \multirow[b]{2}{*}{ Abbreviation } & \multicolumn{2}{|c|}{ HT-29 } & \multicolumn{2}{|c|}{ Caco-2 } & \multicolumn{2}{|c|}{ HIEC } \\
\hline & Mean & SEM & Mean & SEM & Mean & SEM \\
\hline untreated & $100 \%$ & $100 \%$ & $100 \%$ & $100 \%$ & $100 \%$ & $100 \%$ \\
\hline LNT & $110 \cdot 3$ & $5 \cdot 4$ & $102 \cdot 2$ & $6 \cdot 3$ & $100 \cdot 3$ & $8 \cdot 4$ \\
\hline LNH & $120 \cdot 3$ & $10 \cdot 3$ & $100 \cdot 2$ & $8 \cdot 4$ & $102 \cdot 2$ & $5 \cdot 4$ \\
\hline LNFP I & $104 \cdot 3$ & $6 \cdot 4$ & $103 \cdot 2$ & $4 \cdot 4$ & 99.4 & $6 \cdot 6$ \\
\hline LNFP II & $125 \cdot 2$ & $10 \cdot 2$ & $94 \cdot 3$ & $9 \cdot 2$ & $89 \cdot 6$ & $8 \cdot 3$ \\
\hline LNFP III & $123 \cdot 2$ & $9 \cdot 2$ & $98 \cdot 2$ & $4 \cdot 3$ & $100 \cdot 4$ & $9 \cdot 2$ \\
\hline LNDFH I & $119 \cdot 2$ & $9 \cdot 3$ & $99 \cdot 7$ & $8 \cdot 3$ & $104 \cdot 3$ & $4 \cdot 3$ \\
\hline LNDFH II & $154 \cdot 2^{*}$ & $12 \cdot 1$ & $100 \cdot 1$ & $5 \cdot 5$ & $104 \cdot 2$ & $7 \cdot 4$ \\
\hline $2^{\prime} \mathrm{FL}$ & $98 \cdot 3$ & $6 \cdot 4$ & $101 \cdot 2$ & 4.9 & $111 \cdot 2$ & $7 \cdot 3$ \\
\hline 3-FL & $98 \cdot 3$ & $6 \cdot 4$ & 99.6 & $6 \cdot 6$ & $100 \cdot 3$ & $8 \cdot 4$ \\
\hline SL-mixture & $125 \cdot 3^{\star}$ & $6 \cdot 5$ & $102 \cdot 4$ & 4.9 & $132 \cdot 2^{*}$ & 5.9 \\
\hline $3^{\prime}-S L$ & $129 \cdot 3^{*}$ & $6 \cdot 2$ & $105 \cdot 3$ & $5 \cdot 4$ & $126 \cdot 3^{*}$ & $5 \cdot 4$ \\
\hline $6^{\prime}-S L$ & $155 \cdot 3^{* *}$ & $5 \cdot 1$ & $99 \cdot 4$ & $10 \cdot 2$ & $137 \cdot 5^{\star}$ & $6 \cdot 2$ \\
\hline LST a & $98 \cdot 4$ & $7 \cdot 5$ & $106 \cdot 5$ & $7 \cdot 2$ & $100 \cdot 2$ & $6 \cdot 6$ \\
\hline LST b & $96 \cdot 3$ & $6 \cdot 5$ & $89 \cdot 3$ & $7 \cdot 7$ & $96 \cdot 3$ & $8 \cdot 3$ \\
\hline LST c & $99 \cdot 3$ & $4 \cdot 3$ & $106 \cdot 4$ & $8 \cdot 3$ & $98 \cdot 3$ & $7 \cdot 7$ \\
\hline DSLNT & $97 \cdot 5$ & $7 \cdot 6$ & $100 \cdot 3$ & $5 \cdot 4$ & 94.4 & $7 \cdot 4$ \\
\hline
\end{tabular}

${ }^{1}$ Each value represents the mean \pm SEM from three independent experiments $(n)$ ).

${ }^{2}$ The growth inhibition is given as $\%$ of control.

${ }^{3}$ Means differ from control $\left({ }^{\star} P<0.05\right.$ and $\left.{ }^{\star \star} P<0.01\right)$.

Concentrations used were the same as in Table 3.

For abbreviations see Table 1 and 2.

Effect of human milk oligosaccharides on early marker of apoptosis (caspase-3 like activity)

As shown in Fig. 5, only HT-29 cells and HIEC but not Caco2 cells were sensitive to neutral HMO at the highest concentration of $15 \mathrm{mg} / \mathrm{ml}$. The induction of apoptosis was almost 3 -fold in HT-29 cells and about 2-fold in HIEC cells. In contrast, the treatment with acidic HMO fractions did not change caspase- 3 activity in comparison to control cells (data not shown). Also, when screening for individual compounds

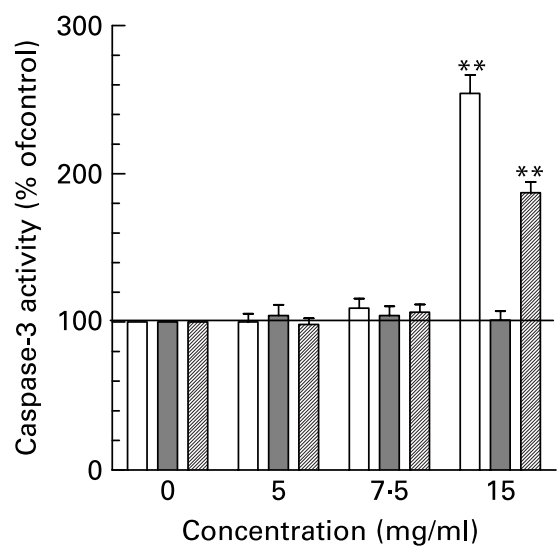

Fig. 5. Apoptotic effects of oligosaccharides in intestinal cells. Intestinal cells were cultured with $0,5,7$ and $15 \mathrm{mg} / \mathrm{ml}$ of neutral $\mathrm{HMO}$ over $24 \mathrm{~h}$ and the degree of treatment-induced apoptosis was assessed using the caspase-3 assay as described in the materials and methods. Apopain activity in control cells was $0.056 \pm 0.005 / h / 10^{6}$ cells (HT-29), $0.046 \pm 0,004 / \mathrm{h} / 10^{6}$ cells (HIE) and $0.049 \pm 0.007 / \mathrm{h} / 10^{6}$ cells (Caco-2) and was set to $100 \%$. Data points are given as mean \pm SEM of three independent experiments performed in triplicates $\left.{ }^{\star *} P<0.01\right)$ none of the oligosaccharide standards showed an effect on caspase-3 (data not shown).

\section{Discussion}

As gut maturation occurs during the last trimester of intrauterine life and continues after birth, the first weeks of the postnatal period are of extraordinary interest with regard to intestinal development ${ }^{2-25}$. Morphogenic changes are directly related to physiologic functions of the gut and are influenced by various dietary factors ${ }^{19,21}$. The aim of the present study was to investigate a possible direct impact of HMO on the growth of intestinal cells by using different cell lines representing different stages of intestinal cell development (Fig. 1), all of which are well established as in vitro models.

We demonstrated a concentration-dependent inhibition of growth of neutral and acidic HMO fractions as well as of some single oligosaccharides present in human milk in HT29, Caco-2 and HIEC cells. However, the effects varied between cell lines. HT-29 and Caco-2 cells were more sensitive to growth inhibition than HIEC cells (Fig. 3).

This difference was observed at all concentrations tested with a threshold at about $7.5 \mathrm{mg} / \mathrm{ml}$ but was mostly pronounced at the highest concentration $(15 \mathrm{mg} / \mathrm{ml})$.

At the highest level, we also observed a stimulatory effect of both neutral and acidic HMO fractions on cell differentiation in HT-29 and HIEC cells but not in Caco-2 cells (Fig. 4). AP activity as a marker of cell differentiation was significantly enhanced in HT-29 and HIEC cells after they had been exposed to 7.5 or $15 \mathrm{mg} / \mathrm{ml}$ acidic HMO. A similar tendency for both concentrations has been observed for neutral HMO fractions, although statistically significant only at $15 \mathrm{mg} / \mathrm{ml}$. 
Thus, the reason for the higher sensitivity of HT-29 to growth inhibition compared with HIEC cells could be that HIEC cells are more susceptible to an induction of differentiation. In the case of Caco- 2 cells, the failure to enhance differentiation was expected since these cells already represent a more differentiated phenotype. To confirm the postulated differentiation-dependent effect we compared the basal AP activity of the different cell lines and determined activities of 0.193 (SEM 0.023), 0.185 (SEM 0.005) and 0.609 (SEM $0 \cdot 013) \Delta \mathrm{E} / \mathrm{h} / 10^{6}$ cells for HT-29, HIEC and Caco-2, respectively. These differences in the cell differentiation phenotype support our hypothesis and were also observed by others $^{42-45}$. The influence of acidic oligosaccharide fractions on differentiation was confirmed by individual acidic oligosaccharides. The strongest effect was found for $3^{\prime}$ - and $6^{\prime}$-sialyllactose. As sialyllactose is the major acidic oligosaccharide in human and bovine milk considerations of supplementing infant formula with such components is supported by this observation $^{46}$.

With regard to apoptosis, it was shown that all cell lines were non-susceptible to acidic HMO fractions. This observation, i.e. a failure of apoptosis induction, may be explained by the more differentiated phenotype (Caco-2) or the induction of differentiation (HT-29 and HIEC cells) by acidic oligosaccharides. Neutral HMO, however, were able to induce a marked increase of caspase-3 activity in HT-29 and HIEC cells supporting the hypothesis of differentiation-associated processes (Fig. 5); again, no effect was seen in Caco-2 cells.

The limited capacity to influence apoptosis or differentiation processes in Caco- 2 cells could be due to the different interaction of oligosaccharides with for example, cell surface receptors and, hence, the generation of a different intracellular signalling response. We assume that the interaction of oligosaccharides with cell surface receptors is differentially regulated in the three cell lines. As the involvement of oligosaccharides in growth factor signaling is well known ${ }^{47}$ our data support a link between oligosaccharide cell surface interaction and growth related effects. Furthermore, a cell surface interaction could induce differences in cell signalling. Mediators of cell cycle events such as cylins, cyclin-dependent kinases (CDK) and their counterparts, the CDK-inhibitors, participate in these processes. When interacting with growth factor receptors it is conceivable that oligosaccharidemediated activation of $\mathrm{CDK}$-inhibitors and $\mathrm{G}_{2}-\mathrm{M}$ cell cycle arrest is required for the induction of differentiation and apoptosis in these intestinal cells ${ }^{31,48}$

When differentiated cells like Caco-2 cells express lower levels of cyclins or CDK they should be less responsive to apoptosis induced by oligosaccharides compared with HT-29 and HIEC cells expressing higher levels of such cell cycles regulators. This observation is an accepted mechanism comparing cancer and non-cancer cells ${ }^{49-51}$.

The specific differences found between the less differentiated HT-29 and HIEC and the more differentiated Caco-2 cells suggest that oligosaccharides act through different mechanisms possibly depending on upon their differentiation phenotype $^{52,53}$.

To identify individual components for the observed growthrelated effects of neutral and acidic HMO, the same experiments were repeated with standard oligosaccharides. The use of individual components, however, did not completely confirm the observed effects of neutral and acidic oligosaccharide fractions. In the case of HT-29, all tested compounds, except for $2^{\prime} \mathrm{FL}$ and 3-FL, led to a dose-dependent growth inhibition but without distinguishable structure-function relationship. Also, several acidic oligosaccharides inhibited the growth of HIEC and Caco-2 cells, whereas among neutral oligosaccharides only LNDFH II had an effect.

While the inhibition of growth can in part be attributed to several selected substances, this was not possible for differentiation and apoptosis. In HT-29, the use of LNDFH II as neutral oligosaccharide induced cell differentiation, but neither Caco-2 nor HIEC differentiation was influenced by any of the tested neutral oligosaccharides. The enhancement of caspase- 3 activity in HT-29 and HIEC cells by neutral HMO (Fig. 5) was not influenced by the selected single compounds at indicated concentration. As there are many different oligosaccharides in human milk, it is easily conceivable that other components not tested in the present study might be responsible for the observed effects.

In summary, we observed a pronounced growth inhibition effect on intestinal epithelial cells by both, neutral and acidic milk oligosaccharide fractions. Effects on differentiation in Caco-2 and HIEC cells were mostly pronounced for acidic and neutral oligosaccharide fractions at $15 \mathrm{ml} / \mathrm{ml}$ with a threshold at about $7.5 \mathrm{mg} / \mathrm{ml}$. Regarding neutral HMO fractions growth inhibition was associated with induction of differentiation and apoptosis in undifferentiated cells such as HT-29 and HIEC cells. In addition, we identified some single neutral compounds responsible for these effects. On the other hand, growth arrest in HT-29 and HIEC cells induced by acidic oligosaccharides was associated with effects on differentiation but not on apoptosis. Thus, HMO were shown to induce growth inhibition in different intestinal cells through two different mechanisms, (i) by suppressing cell cycle progression through induction of differentiation and/or (ii) by influencing apoptosis. Based on these observations, oligosaccharides at physiologically relevant concentrations may serve as modulators of maturational intestinal changes.

\section{Acknowledgements}

The authors would like to thank Ms Nadine Metz for her excellent technical assistance. The present study was supported by Wyeth Nutrition, 500 Arcola Road, Collegeville, PA 19426 USA. The authors declare no conflict of interest.

\section{References}

1. Schack-Nielsen L \& Michaelsen KF (2006) Breast feeding and future health. Curr Opin Clin Nutr Metab Care 9, 289-296.

2. Lawrence RA (2004) Breast milk and infection. Clin Perinatol 31, 501-528.

3. Schanler RJ \& Atkinson SA (1999) Effects of nutrients in human milk on the recipient premature infant. J Mammary Gland Biol Neoplasia 4, 297-307.

4. Kunz C \& Rudloff S (1993) Biological functions of oligosaccharides in human milk. Acta Paediatr 82, 903-912.

5. Sharon N \& Ofek I (2000) Safe as mother's milk: carbohydrates as future anti-adhesion drugs for bacterial diseases. Glycoconj $J$ 17, 659-664. 
6. Fava F, Lovegrade JA, Gitau R, Jackson KG \& Tuohy KM (2006) The gut microbiota and lipid metabolism: implications for human health and coronary disease. Curr Medical Chem 13, 3005-3021.

7. Bode L, Rudloff S, Kunz C, Strobel S \& Klein N (2004) Human milk oligosaccharides reduce platelet-neutrophil complex formation leading to a decrease in neutrophil $\beta 2$ integrin expression. J Leukoc Biol 76, 820-826.

8. Bode L, Kunz C, Muhly-Reinholz M, Meyer K, Seeger W \& Rudloff S (2004) Inhibition of monocyte, lymphocyte, and neutrophil adhesion to endothelial cells by human milk oligosaccharides. Thromb Haemost 92, 1402-1410.

9. Brew K \& Hill RL (1975) Lactose biosynthesis. Rev Physiol Biochem Pharmacol 72, 105-158.

10. Charron M, Shaper JH \& Shaper NL (1998) The increased level of $\beta 1,4$-galactosyltransferase required for lactose biosynthesis is achieved in part by translational control. Proc Natl Acad Sci U S A 95, 14805-14810.

11. Stahl B, Thurl S, Zeng J, Karas M, Hillenkamp F, Steup M \& Sawatzki G (1994) Oligosaccharides from human milk as revealed by matrix-assisted laser desorption/ionization mass spectrometry. Anal Biochem 223, 218-223.

12. Kunz C, Rudloff S, Schad W \& Braun D (1999) Lactose-derived oligosaccharides in the milk of elephants: comparison with human milk. Br J Nutr 82, 391-399.

13. Kunz C \& Rudloff S (2000) Oligosaccharides in human milk: structural, functional, and metabolic aspects. Аnпи Rev Nutr 20, 699-722.

14. Gnoth MJ, Kunz C, Kinne-Saffran E \& Rudloff S (2000) Human milk oligosaccharides are minimally digested in vitro. J Nutr 130, 3014-1320.

15. Rudloff S, Pohlentz G, Diekmann L, Egge E \& Kunz C (1996) Urinary excretion of lactose and oligosaccharides in preterm infants fed human milk or infant formula. Acta Paediatr $\mathbf{8 5}$, 598-603.

16. Engfer MB, Stahl B, Finke B, Sawatzki G \& Daniel H (2000) Human milk oligosaccharides are resistant to enzymatic hydrolysis in the upper gastrointestinal tract. Am J Clin Nutr 71, 1589-1596.

17. Gnoth MJ, Rudloff S, Kunz C \& Kinne RK (2001) Investigations of the in vitro transport of human milk oligosaccharides by a Caco- 2 monolayer using a novel high performance liquid chromatography-mass spectrometry technique. J Biol Chem 276, 34363-34370.

18. Bode L (2006) Recent advances on structure, metabolism, and function of human milk oligosaccharides. J Nutr 136, $2127-2130$.

19. Donovan SM (2006) Role of human milk components in gastrointestinal development: Current knowledge and future needs. J Pediatr 149, 49-61.

20. Ichiba H, Kusuda S, Itagane Y, Fujita K \& Issiki G (1992) Measurement of growth promoting activity in human milk using a fetal small intestinal cell line. Biol Neonate 61, 47-53.

21. Takeda T, Sakata M, Minekawa R, Yamamoto T, Hayashi M, Tasaka K \& Murata Y (2004) Human milk induces fetal small intestinal cell proliferation - involvement of a different tyrosine kinase signaling pathway from epidermal growth factor receptor. J Endocrinol 181, 449-457.

22. Sreedharan R \& Mehta DI (2004) Gastrointestinal tract. Pediatrics 113, 1044-1050.

23. Karam SM (1999) Lineage commitment and maturation of epithelial cells in the gut. Front Biosci 4, 286-298.

24. Studzinski GP \& Harrison LE (1999) Differentiation-related changes in the cell cycle traverse. Int Rev Cytol 189, 1-58.

25. Walker WA (2004) The dynamic effects of breastfeeding on intestinal development and host defense. Adv Exp Med Biol 554, $155-170$.
26. Wagner CL, Forsythe DW \& Wagner MT (1998) The effect of recombinant TGF $\alpha$, human milk, and human milk macrophage media on gut epithelial proliferation is decreased in the presence of a neutralizing TGF $\alpha$ antibody. Biol Neonate 74, 363-371.

27. Desloges N, Basora N, Perreault N, Bouatrouss Y, Sheppard D \& Beaulieu JF (1998) Regulated expression of the integrin $\alpha 9 \beta 1$ in the epithelium of the developing human gut and in intestinal cell lines: relation with cell proliferation. J Cell Biochem 71, $536-545$.

28. Basora N, Vachon PH, Herring-Gillam FE, Perreault N \& Beaulieu JF (1997) Relation between integrin $\alpha 7 B \beta 1$ expression in human intestinal cells and enterocytic differentiation. Gastroenterology 113, 1510-1521.

29. Escaffit F, Perreault N, Jean D, et al. (2005) Repressed E-cadherin expression in the lower crypt of human small intestine: a cell marker of functional relevance. Exp Cell Res 302, $206-220$

30. Sambuy Y, De Angelis I, Ranaldi G, Scarino ML, Stammati A \& Zucco F (2005) The Caco-2 cell line as a model of the intestinal barrier: influence of cell and culture-related factors on Caco-2 cell functional characteristics. Cell Biol Toxicol 21, $1-26$.

31. Tremblay E, Auclair J, Delvin E, Levy E, Ménard D, Pshezhetsky AV, Rivard N, Seidman EG, Sinnett D, Vachon PH \& Beaulieu JF (2006) Gene expression profiles of normal proliferating and differentiating human intestinal epithelial cells: a comparison with the Caco-2 cell model. J Cell Biochem 99, $1175-1186$.

32. Graz CJ \& Cowley HM (1997) Energy state in HT-29 cells is linked to differentiation. In Vitro Cell Dev Biol Anim 33, 277-281.

33. Thomson AB, Doring K, Keelan M \& Amstrong G (1997) Nutrient uptake into undifferentiated and differentiated HT-29 cells in culture. Can J Physiol Pharmacol 75, 351-356.

34. Kunz C, Rudloff S, Hintelmann A, Pohlentz G \& Egge H (1996) High-pH anion-exchange chromatography with pulsed amperometric detection and molar response factors of human milk oligosaccharides. J Chromatogr B Biomed Appl 685, 211-221.

35. Rudloff S, Obermeier S, Borsch C, Pohlentz G, Hartmann R, Brösicke H, Lentze MJ \& Kunz C (2006) Incorporation of orally applied ${ }^{13} \mathrm{C}$-Galactose into milk lactose and oligosaccharides. Glycobiology 16, 477-487.

36. Pageot LP, Perreault N, Basora N, Francoeur C, Magny P \& Beaulieu JF (2000) Human cell models to study small intestinal functions: recapitulation of the crypt-villus axis. Microsc Res Tech 49, 394-406.

37. Fogh J \& Trempe G (1975) New human tumor cell lines. In Human Tumor Cells in Vitro, pp. 115-159 [J Fogh, editor]. New York: Plenum Press.

38. Perreault N \& Beaulieu JF (1996) Use of the dissociating enzyme thermolysin to generate viable human normal intestinal epithelial cell cultures. Exp Cell Res 224, 354-364.

39. Kuntz S, Wenzel U \& Daniel H (1999) Comparative analysis of the effects of flavonoids on proliferation, cytotoxicity, and apoptosis in human colon cancer cell lines. Eur J Nutr 38, 133-142.

40. Kuntz S, Wenzel U, Brendel M \& Daniel H (2000) Dietary flavone selectively induces apoptosis in human colon carcinoma cells. Cancer Res 60, 3823-3831.

41. Nicholson DW, Ali A, Thornberry NA, et al. (1995) Identification and inhibition of the ICE/CED-3 protease necessary for mammalian apoptosis. Nature 376, 37-43.

42. Comalada M, Bailon E, de Haro O, Lara-Villoslada F, Xaus J, Zarzuelo A \& Galvez J (2006) The effects of short-chain fatty acids on colon epithelial proliferation and survival depend on the cellular phenotype. J Cancer Res Clin Oncol 132, 487-497. 
43. Lenaerts K, Mariman E, Bouwman F \& Renes J (2005) Differentiation stage-dependent preferred uptake of basolateral (systemic) glutamine into Caco- 2 cells results in its accumulation in proteins with a role in cell-cell interaction. FEBS J 272, 3350-3364.

44. Comalada M, Bailon E, de Haro O, Lara-Villoslada F, Xaus J, Zarzuelo A \& Galvez J (2006) The effects of short-chain fatty acids on colon epithelial proliferation and survival depend on the cellular phenotype. J Cancer Res Clin Oncol 132, 487-497.

45. Gamet L, Daviaud D, Denis-Pouxviel C, Remesy C \& Murat JC (1992) Effects of short-chain fatty acids on growth and differentiation of the human colon-cancer cell line HT29. Int J Cancer 52, 286-289.

46. Wang B, Bing Y \& Karim M (2007) Dietary sialic acid supplementation improves learning and memory in piglets. Am J Clin Nutr 85, 561-569.

47. Cai W, He JC, Zhu L, Lu C \& Vlassara H (2006) Advanced glycation end product (AGE) receptor 1 suppresses cell oxidant stress and activation signaling via EGF receptor. Proc Natl Acad Sci U S A 103, 13801-13806.

48. Dydensborg AB, Herring E, Auclair J, Tremblay E \& Beaulieu JF (2006) Normalizing genes for quantitative RT-PCR in differentiating human intestinal epithelial cells and adenocarcinomas of the colon. Am J Physiol Gastrointest Liver Physiol 290, 1067-1074.

49. Gomez LA, de Las Pozas A, Reiner T, Burnstein K \& PerezStable C (2007) Increased expression of cyclin B1 sensitizes prostate cancer cells to apoptosis induced by chemotherapy. Mol Cancer Ther 6, 1534-1543.

50. Yano M, Naito Z, Yokoyama M, Shiraki Y, Ishiwata T, Inokuchi M \& Asano G (1999) Expression of hsp90 and cyclin D1 in human breast cancer. Cancer Lett 137, 45-51.

51. Benitez DA, Pozo-Guisado E, Alvarez-Barrientos A, FernandezSalguero PM \& Castellón EA (2007) Mechanisms involved in resveratrol-induced apoptosis and cell cycle arrest in prostate cancer-derived cell lines. J Androl 28, 282-293.

52. Hinnebusch BF, Ma Q, Henderson JW, Siddique A, Archer SY $\&$ Hodin RA (2002) Enterocyte response to ischemia is dependent on differentiation state. J Gastrointest Surg 6, 403-409.

53. Pshezhetsky AV, Fedjaev M, Ashmarina L, et al. (2007) Subcellular proteomics of cell differentiation: Quantitative analysis of the plasma membrane proteome of Caco-2 cells. Proteomics 5, 2201-2215. 